\title{
WOMEN IN PAKISTAN- SOCIAL MOBILITY, HUMAN DEVELOPMENT AND EMPOWERMENT
}

\author{
Sidra Ahmed* \\ Samreen Bari Aamir** \\ Rizwana Jabeen $^{* * *}$
}

\begin{abstract}
The word Development is devious and captivating, however, the development path is perplexed. In most cases, the governments try to attain economic, military, technological, and infrastructural development, whereas, the power centers evade investing and working on issues of Human Development. The governments of countries like Pakistan strive to shuffle the attentiveness of the world by spending a huge amount on building the roads, on bridges, and transportation and in maximization of arms and ammunition. Human development in Pakistan has always been neglected due to various reasons. A huge population of almost a 22million having as low as 154 th (out of 189 countries) position in the human development index. The patriarchal system has created the social and cultural environment that is supporting persistence male domination, remains the major obstacle in the intellectual, social, and economic growth of women. This paper addresses the conceptual and methodological aspects of human development and women's empowerment in Pakistan, it explains the challenges and trends concerning women's empowerment throughout Pakistan's history, specifically in key areas such as individual, education, and health, economic and political participation, and especially Women's limited and controlled mobility.
\end{abstract}

Keywords: Women empowerment; social mobility; culture; Pakistan; human development; social mobility

\section{Introduction}

Human development is substantial to revamp an unproductive, incognizant, benighted, unskilled and powerless person to a productive, an effective, prolific, apprehensive, cognizant, skilled, educated, and health-conscious individual. Human development cooperates an individual to reinvent his productive soul. As $\mathrm{UNDP}^{1}$ explained;

The human development approach focuses on improving the lives people lead rather than assuming that economic growth will lead, automatically, to greater

\footnotetext{
This work is Licensed under a Creative Commons Attribution-Non-Commercial 4.0 International License. @) (1) (8)

* Sidra Ahmed, Lecturer, International Relations Program, DHA Suffa University

** Samreen Bari Aamir, Visiting Lecturer, Bahria University, Karachi Campus

*** Rizwana Jabeen, Ph.D. Assistant Professor, Department of International Relations, Federal Urdu University of Arts, Science and Technology, Abdul Haq Campus, Karachi

${ }^{1}$ UNDP. United Nations Development Programme. Oxford: Oxford University Press, 1990. (the new concept of Human development was introduced in 1990 for promoting human wellbeing)
} 
opportunities for all. Income growth is an important means to development, rather than an end in itself. Human development is about giving people more freedom and opportunities to live lives they value. In effect, this means developing people's abilities and giving them a chance to use them. ${ }^{2}$

The primitive objective is to create awareness. When governments invest in people, they, in return, develop and groom their capabilities and learn how to live long and healthy lives.

It is a fact that satisfied minds laid the foundation of a progressive and positive society therefore we can say that through human development; governments would be able to groom, support, and formulate a tolerant, modern, educated, skilled, law-abiding, and progressive, and creative culture. Ken Robinson ${ }^{1}$ beautifully described the importance of Human development with these words:

You cannot predict the outcome of human development. All you can do is like a farmer create the conditions under which it will begin to flourish.

GDP or GNP of any country is no more the meticulous indicator or cannot predict the wellbeing and prosperity of its common citizen. Development is the availability of opportunities for common people regardless of their sex, race, age group, ethnicity, and social status, development is the escalation of choices and providing freedom to every individual in setting up their future goals so that people feel free in choosing their destiny. This can only be achieved once the society can provide equal economic opportunities when there are free, available, and up to the mark educational facilities available when there is no corruption in the society, when there are no issues of governance, and when the health facilities are readily available. It is quite alarming that Pakistan's ranking is continuously in decline as far as the human development index is concerned. It was 147 th in 2015 , then Pakistan attained the $152^{\text {nd }}$ position in 2019, and now Pakistan has been ranked 154th among 189 countries on UN's Human Development Index (HDI) 2020 rankings. It is important to note that the HDI rankings are measured by analyzing different factors like health and education facilities, the overall standard of living, availability of food and shelter, and also the emission of the nation's carbon dioxide and material footprint. ${ }^{3},{ }^{4}$

Gender inequality is a major reason behind the deprived human development condition. The increasing inequalities between men and women in every walk of life are alarming. Even though women are considered as highly important parts or the backbone of our social setup; they face unlimited hindrances throughout their lives to gain equal rights, power, and respect. No country can face the challenges of the global world without the involvement of almost fifty percent or half of its population. It is inevitable to empower them "as the empowerment and independence of women and the enhancement of

\footnotetext{
2 Jain, S. (2020). Human Development, Gender and Capability Approach. Indian Journal of Human Development. 14(2), 320 -322.

${ }^{3}$ Tribune, Express. "Pakistan ranks 154th on UN's Human Development Index." The Express Tribune, 0309 , 2021.

${ }^{4}$ Ahmed, Syed Shujaat. "Human development in Pakistan: challenges and way forward." Daily Times, 12 27, 2019.
} 
their political, social, financial and health status is a highly important end in itself. Besides, it is essential for the achievement of sustainable development. The full participation and partnership of both women and men are required in productive and reproductive life, including shared responsibilities for the care and nurturing of children and maintenance of the household". 5

\section{Objective of study}

- The basic objective of the study is to understand the concept of human development and to assess the impact of human development on women.

- To analyze and evaluate the empowerment of Pakistani women. (through interviews)

- To identify the problems and offer suggestions to improve the overall condition of Pakistani women.

\section{Research Questions}

1. To find out the normal decision-making capability of women in Pakistan.

2. To assess and pinpoint the difficulties faced by average Pakistani women in getting an education and in uplifting the financial status.

3. To give suggestions and recommendations to boost women's empowerment in Pakistan through conducting interviews with empowered professional women.

\section{Methodology}

The qualitative research method was adopted in collecting, organizing, reviewing, and inferring the importance of human development and its probable impact on Pakistani women. The basic aim of the study was to seek the answers to research questions by analyzing the available evidence and by conducting the interviews with relevant eminent empowered Pakistani women.

\section{Theoretical Overview}

The concept of human development, which further elucidates the issue of empowerment and social mobility, has been defined and explained by many eminent economists and theoreticians. The work of Dr. Mehbub-ul-Haq and Amartya Sen has been exclusively applied in this article to build a conceptual grounding. ${ }^{6}$

\footnotetext{
${ }^{5}$ Fund, United Nations Population. Women Empowerment. Issue 7, Cairo: UNFPA, 1994.

${ }^{6}$ America, Measure of. About Human Development. n.d.

https://measureofamerica.org/humandevelopment/\#: :text=Human\%20development $\% 20$ is $\% 20$ defined $\% 20$ as,a nd $\% 20$ improving $\% 20$ their $\% 20$ well $\% 2$ Dbeing.\&text $=$ The $\% 20$ human $\% 20$ development $\% 20$ concept $\% 20$ was $\% 2$ 0developed\%20by\%20economist\%20Mahbub\%20ul\%20Haq. (accessed 03 11, 2021).
} 
Dr. Mahbubulhaq is the architect and the campaigner of the concept to humanize economics for the wellbeing of common people. He was a strong supporter of awarding a human face to economic development and firmly assumed that human development is far more important than the richness of the government. He strongly believed that:

The purpose of development is not just to enlarge incomes but to enlarge people's choices, and that these choices extend to a decent education, good health, political freedom, cultural identity, personal security, community participation, environmental security, and many other areas of human wellbeing. 7

D. Haq mentioned ${ }^{8}$ four core principles to assess the human development process. These principles are equity, efficiency, participation, and sustainability.

Equity: It denotes the notion of impartiality, neutrality, and evenhandedness. Human development is the deliverance of justice as well as the availability or access of opportunities to every individual. It is important to mention that concepts of equity and equality are different from each other. Equity identifies that the people in disadvantageous conditions due to unequal opportunities can be treated differently as it is inevitable to treat them with favored conduct or with positive action. For example, the poor, differentlyabled, women, ethnic minorities, and minorities.

Efficiency: Efficiency can be defined as the optimum usage of current assets. According to the human development approach, "efficiency is defined as the least cost method of reaching the goals through various interventions that maximize opportunities for individuals and communities through optimal use of human and material and institutional resources"9. It is important to consider the situation while applying this principle as what is efficient in a given situation may be inefficient in some other period or long run.

Participation and empowerment: A highly important aspect of human development is the empowerment of the mind and the whole process that makes individuals capable of making the decisions themselves. "Whether at the level of policy-making or implementation, this principle implies that people need to be involved at every stage not merely as beneficiaries but as agents who can pursue and realize goals that they value and have reason to value ${ }^{10}$ ".

Sustainability: human development explains sustainability in terms of social, political, and financial spheres. We can refer to this process in various fields for example financial stability demands sustainability where development is financed. "Specifically, development should not lead countries into debt traps. Social sustainability refers to how social groups and other institutions are involved in ensuring participation and involvement

\footnotetext{
${ }^{7}$ LUMS. Mahbubulhaq research centre. n.d. https://mhrc.lums.edu.pk/history-3 (accessed 10 31, 2020).

${ }^{8}$ Mahbubulhaq. Reflections on Human development. Berlin: Oxford University Press, 1995

${ }^{9}$ Deneulin, Sabina Alkire and Séverine. " Introducing the Human Development and Capability Approach (Chapter 2)." In An Introduction to the Human Development and Capability Approach: Freedom and Agency, by Lila Shahani Severine Deneulin, 1-22. Routledge, 2009.

${ }^{10}$ beecher-stowe-quotes-3530095 (accessed 11 05, 2020).

LUMS. Mahbubulhaq research centre. $n . d$. https://mhrc.lums.edu.pk/history-3 (accessed 10 31, 2020).
} 
and avoiding disruptive and destructive elements. Cultural liberty and respect for diversity are also important values that can contribute to socially sustainable development". ${ }^{11}$

Other prominent names in explaining the human development approach are Amartya $\mathrm{Sen}^{12}$ and Nussbaum ${ }^{13}$. Amartya Sen provided the individualistic explanation of human development. The main focus is on the enlargement and expansion of individual freedom and refinement of individual capabilities. The basic aim is to encourage people to explore and expand their potentials. This can only be done when an individual is free to make choices and is ready to explore and assess its potential by doing a variety of things this is called "functioning"." It is these functioning that we observe. The human development approach tends to focus on functioning rather than abilities because of its major concern with assessing progress since functioning can be observed and measured. It is much more difficult to measure capabilities ${ }^{14}$ ". Autonomy of individual choice is a significant feature of human development. As mentioned clearly in Human Development Report, "Human development is a process of enlarging people's choices ${ }^{15}$ ". Hence it is clear that if a usual functioning is not selected without restrictions, this would be a severe deficiency.

Freedom of choice is central to the approach: someone choosing to be hungry (during a religious fast say) is quite different from someone hungry because they cannot afford to buy food. It is evident that the subject matter of human development is increasing choices and awareness; and capabilities of individuals.

\begin{abstract}
Human development is about putting people at the center of development. It is about people realizing their potential, increasing their choices, and enjoying the freedom to lead lives they value. ${ }^{16}$
\end{abstract}

\title{
What is empowerment?
}

As we have discussed before the human development approach, empowerment is the situation or process when people assume themselves as strong enough and capable enough to make life decisions. This stage can only be achieved when people consider themselves free and independent. "Whether at the level of policy-making or implementation, this principle implies that people need to be involved at every stage not merely as beneficiaries but as agents who can pursue and realize goals that they value and have reason to value ${ }^{17}$ ".

Empowerment helps people to discover their capabilities and hidden talent and these capabilities can be maximized when an individual found himself independent and free in making decisions and leads a life with his own free will. Amartya Sen was a great

\footnotetext{
${ }^{11}$ Ibid

${ }^{12}$ Sen, Amrtya. Development as Freedom. Oxford: Oxford University Press, 1999

${ }^{13}$ Nussabaum, M. Women and Human Development:A Study in Human Capabilities. . Cambridge: Cambridge University Press, 2000.

${ }^{14}$ Stewart, Frances. Capabilities and Human development. New York: UNDP, 2013.

${ }^{15}$ UNDP. United Nations Development Programme. Oxford: Oxford University Press, 1990.

${ }^{16}$ UNDP. Human Development Report. New York: Palgrave Macmillan, 2009.

${ }^{17}$ Department (West) , ADB, 2000

Deneulin, Sabina Alkire and Séverine. " Introducing the Human Development and Capability Approach (Chapter 2)." In An Introduction to the Human Development and Capability Approach: Freedom and Agency, by Lila Shahani Severine Deneulin, 1-22. Routledge, 2009.
} 
supporter of the idea that development is in actual the expansion of people's choices he explains this concept in "Development as Freedom". According to him, Freedom is a key determining factor of an individual's initiatives and social effectiveness ${ }^{18}$.

Batliwala explained empowerment as "how much influence people have over external actions that matter to their welfare" 19 Kabeer defines empowerment as "the expansion in people's ability to make strategic life choices in a context where this ability was previously denied to them." 20

Though defined in feminist literature in the 1970s, empowerment became popular in the development field in the 1980s.In 1981, Julian Rappaport Emeritus Professor of Psychology at the University of Illinois at Urbana-Champaign - University of Illinois conceived the concept 'empowerment' and proposed to adopt the social behavior that can change and help the people to overcome their social problems stemming from powerlessness. Through this approach, he emphasized that society can bring positive changes and bring development and progress in every aspect of life and can minimize or reduce the social problems of individuals. Empowerment includes considering people's needs, their rights, and their choices, and it captures the breadth of concern with the powerlessness that many groups experience" ${ }^{21}$.

Ideally speaking empowerment is not a static or hidden behavior of an individual or a society it is a continuous, multidimensional, adopted, groomed, and dynamic social process that helps and educates people and to helps them to achieve the level of selfactualization. It is a mechanism that fosters power in people for use in their own lives, their communities, and in their society, by acting on issues they define as important. Individual change is a prerequisite for community and social change and empowerment.

\section{Human development and its impact on Women Empowerment}

This is an undeniable fact of contemporary times that the dream of human development cannot be achieved without women's empowerment and their participation in economic activities with their complete potentialities. The aspiration of sustainable, effective, and progressive human development goals cannot be achieved without empowering the basic foundation of a society that is - Women.

\footnotetext{
${ }^{18}$ Sen, Amartya. Development as freedom. New York: First Anchor Books, 2000.

${ }^{19}$ Tandon, Dr Tanu. "Women Empowerment: Perspectives and Views ." The International Journal of Indian Psychology, 2016: 6-16.

${ }^{20}$ Kabeer, Naila. "Resources, Agency, Achievements:Reflections on the Measurement of Women's Empowerment." In Discussing Women's Empowerment, by Anne Sisask, 17-57. Stockholm: Sida studies, 2001.

${ }^{21}$ Fabricio E. Balcazar, Christopher B. Keys, and Julie A. Vryhof. "Empowerment." In Introduction to Community Psychology, by Olya Glantsman, Jack F. O'Brien, and Kaitlyn N. Ramian Leonard A. Jason. Montreal, Canada: Pressbooks, 2019.
} 
Harriet Beecher Stowe, an American abolitionist, and author declared that:

Women are the real architects of society. ${ }^{22}$

Therefore, it is inevitable to motivate and empower women to play active roles in all sectors of society to improve the quality of life for women, men, family, society, community, and nation.

As of January 1, 2019, it was estimated that there were 3,800,750,379 women throughout the world. As of the same date, there were approximately $3,868,358,699$ men. That's a total population of $7,669,109,078$. The United Nations estimates that for every 100 women on the planet, there are 101.7 men. ${ }^{23}$

Yet, a large number of women around the world are unemployed or else not getting paid off against their work which they perform at home, in farms, on fields, etc. another reason for the world economy to suffer and for the slower and poorer human development indicators is the unequal opportunity for women at workplaces due to strict socio-culturalpolitical and religious structures.

\section{Why empowering our women is important?}

\section{Because it's a call of the Time!!}

The tight knitted economically trapped world we are living in has become more economically competitive as well as grueling which requires a cut-throat mechanism that could deliver the best to ensure the overall economic and in a larger context the human development of the countries with poor human development progress. Excluding the women's wisdom, skills, and serving capabilities from the socio-economic pursuit would be sheer folly.

$>$ Women being half of the world's population own the responsibility, just like their male counterparts, of making their world a better place for themselves, their children, and their people.

D Empowering women can lead to a system that will be more accommodating and adaptable for both genders. Shared economic benefits will raise a comparable economic progress.

$>$ Women already serving consistently in existing not so very pleasant state of affairs, whether they are at home or workplace or in any other field of life, empowerment and acknowledgment will further boost their growth and performance

\footnotetext{
${ }^{22}$ Lewis, Jone Johnson. harriet-beecher-stowe-quotes. 07 03, 2019. https://www.thoughtco.com/harrietbeecher-stowe-quotes-3530095 (accessed 11 05, 2020).

${ }^{23} \mathrm{https}: / /$ www.reference.com/world-view/many-women-world-a8e6facca00d95b6
} 
Men can be more benefited from women becoming independent and self-sufficient. Shared economic efforts will lead to more coalition and cohesion within families and among society as a whole.

$>$ Women across the world can experience the positive outcomes of becoming economically sufficient and socially empowered. A healthy, educated, well aware, well informed, self-assured, and progressive woman can form a more stable and harmonious society, compare to a woman who has no voice, no reach no standing in money-making as well as political activity.

Interestingly, men have an observable aptitude for financial corrupting. Different workplace surveys and reports verify this fact that women are more dedicated and honest to their jobs. Letting them into mainstream economic bustle can provide a country a whole lot of efficient, loyal, and well-organized force.

Illiterate, socially and economically demotivated and mentally enslaved women cannot become progressive members of a society and cannot nurture a positive and progressive nation.

Brigham Young stresses the importance of women education with these words:

You educate a man; you educate a man. You educate a woman; you educate a generation. $^{24}$

\section{Women in Pakistan and the wobbly route of empowerment}

No doubt that Pakistani women have excelled in almost every sector, they are Ministers, Ambassadors, teachers, doctors, internationally acclaimed filmmakers and artists, engineers, farmers, entrepreneurs, etc. Therefore it is an open secret that sincere efforts with clarity and determination are required to groom their skills and to educate them and most importantly to empower them so that they can play a significant role in the development of our country. According to the World Bank, female labor participation accounts for only $25 \%$. In the economy of Pakistan, this low figure is putting a huge question mark on governments' efforts for empowering women and the efforts in educating and in refining their skills so this is high time to massively invest in girls' education and to foster their skills and to encourage and groom them to play their required and essential roles. Vocational training programs could be helpful in the development of skills.

A country briefing paper published by Asian Development of Pakistan ${ }^{25}$ clearly stated that;

An artificial divide between production and reproduction, created by the ideology of sexual division of labor, has placed women in reproductive roles as mothers and wives in the private arena of home and men in a productive role as

\footnotetext{
${ }^{24} \mathrm{https} / / /$ www.goodreads.com/quotes/37892-you-educate-a-man-you-educate-a-man-you-educate

${ }^{25}$ Bank, Asian Development. Women in Pakistan. Islamabad: Programs Department (West) and Programs Department (West), ADB, 2000.
} 
breadwinners in the public arena. This has led to a low level of resource investment in women by the family and the State.

While analyzing Pakistan's human development stats, one may discover that the socioeconomic condition of women is the feeblest. Gender is considered one of the basic elements and organizing principles of Pakistani society. Deeply rooted patriarchal culture in actual determines the socio-economic position of a gender. Women in Pakistan are the most deprived and suppressed gender. In 2020 World Economic Forum ranked Pakistan at $151^{\text {st }}$ position just before Iraq and Yemen ${ }^{26}$.

Since its inception, Pakistan has been facing numerous challenges of abundant nature in almost all fields of its socio-economic ambit. But the foremost and primal focus of concern has remained the well-being of its people, curtailment of its shattered human development structure, and the formulation of a unanimous policy to bolster all its societal layers that may comprise the benefits to charm all income classes, genders, and social segments.

As a newly created nation-state that was inflicted with absolute domestic and international challenges, Pakistan had to foster its economic as well as human development condition first before going forward to any other agenda, which sadly didn't happen due to multiple reasons discussed further in this paper. From that time till now we have tested different styles of governance under both military and civilian leadership, but the pursuit for a progressive and developed Pakistan is still nothing but a hard target to achieve influentially and effectively.

The process of globalization has almost eliminated the possibility of a local economy being able to become competitive in the global market by standing itself. However, by prioritizing social development, enabling women to become full participants in the state, and expanding the power and possibilities that civil society groups can play, Pakistan will find that these are the most viable strategies to break free from the debt and poverty trap in which it finds itself today. A global report shows that Pakistani women still face the world's worst inequality in access to health care, education, and work.

\section{Social Mobility}

Pitirim Sorokin ${ }^{27}$ was the first sociologist who introduced the concept of "social mobility". He explained that no society is entirely open and in the meantime, we can say that not every society is closed. As per Sorokin, societies are not the same in the aspect of the facilities and opportunities available, hence because of this fact it is observed that the pace of social mobility is different from one time period to the next. It can determine that how advanced society is. Social mobility as a result of social interaction activates the societal shift of individuals from one position to another. Social mobility does not rely only on few calculated dimensions it is a multidimensional concept that not only indicates

\footnotetext{
${ }^{26}$ Forum, World Economic. Social mobility. World Economic forum, 2020.

${ }^{27}$ Pitirim Alexandrovich Sorokin was a Russian born, American, sociologist and political activist, he introduced the social cycle theory
} 
the change in an individual's status within a particular community but also portrays the financial position and social prestige and power.

Gender is another very important dimension to explain and discuss social mobility. It is highly observed that men and women face and struggle with a different types of social problems and especially it is difficult for women to acquire financial independence. It is a general construct of the society where children born in poor families most probably will likely be poor themselves whereas the children born to rich families will enjoy a luxurious life. The upward mobility of the children born to poor parents is very low throughout the world. Across societies, children born in less privileged families experience more problems than those of affluent families. The case is worst as far as women are concerned. Individual opportunities and chances given by society are usually considered as the most important factors and the majority of the time they are determined at the time of birth. The majority times the socio-economic systems, (individual's background) a lot determines individual's level of education (that they will attain in future), the profession and level of social class they will attain and the level of income they will earn in future. Although John Rawls and Amartya Sen explained that, "in an ideal world, individuals would have the capabilities to prosper, irrespective of their background or personal characteristics" 28

Unfortunately in today's global and interconnected world, the majority of the intergenerational data comprises of father-son comparisons. But a Pew's economic mobility project released a report focusing on women's mobility. It comprises the comparison between baby boomer women and their parents in terms of wages, working hours, and income distribution. The report indicated following finding ${ }^{29}$ :

1. It is a fact that in today's world women are getting higher salaries, rewards, benefits than their mothers but still, they are not getting more wages than their fathers. However, men are getting higher wages compared to their parents.

2. $80 \%$ of the daughters belonging to poor families are getting more wages than their fathers.

3. Although in today's world women are also working to help their spouse in running the family, but men's wages are considered more important in considering family income.

4. Another very interesting aspect that was observed is that the women from the background where mothers did not work are enjoying with highest family incomes that mean the women with a stay at home mother have high earning fathers.

5. Although thorough research is proven that the people stuck to their level of income concerning their family of orientation but it is also an undeniable fact that women

\footnotetext{
${ }^{28}$ Forum, World Economic. Social mobility. World Economic forum, 2020.

${ }^{29}$ Venator, Richard V. Reeves and Joanna. Women and Social Mobility: Six Key Facts. April 03, 2014. https://www.brookings.edu/blog/social-mobility-memos/2014/04/03/women-and-social-mobility-six-keyfacts/ (accessed 1120,2020$)$.
} 
face more problems whether they are at the top or the bottom of the income distribution. It is more likely that women born in poor families and with low-income levels will remain at the bottom than men, vice versa men born in high-income families will remain in that position compared to women.

6. It is anticipated for women to work more for upward mobility especially and particularly to those who are at the bottom of their income level.

7. Low social mobility is both a reason and an outcome of rising imbalances and has unfriendly ramifications for social attachment and comprehensive development. The disparity of chance and imbalance of results give off an impression of being causally and circularly connected.

\section{Empowered Pakistani women on empowerment and social mobility in Pakistan}

Detailed interviews have been conducted with various Pakistani women who are selfmade business entrepreneurs and experts in their respective fields. Keeping in mind the COVID 19's SOPs and the interviewee's convenience the interviews had been conducted in-person and virtually both. We selected women from the fields of academics, multinational publication groups, the beauty industry of Pakistan, and business. The purpose was to assess women's first-hand experience working in different working environments. We enquired whether it is possible to empower women in Pakistani society? We also discussed whether we should have a local version of empowerment that is different from the one in the west? It is also necessary to seek their views on the low social mobility of women in Pakistan hence we tried to gather their views on this topic.

Dr. Huma Baqai $^{30}$ a renowned educationist and political scientist emphasized that it is inevitable to empower our Pakistani women. 'It's a fact that if we want a turn-around in Pakistan, and if we want to move forward, then it is not possible without empowering women. An inclusive strategy is integral for any country to advance. And this is not because the optics are good, or because the developed countries in the west are practicing this, it is because this is simply a requirement, a prerequisite. We cannot ignore fifty percent of the population and expect to do anything at all in the world. We have examples of China and Japan, where the whole community, including women, was provided with equal educational and job opportunities, and women were specially empowered, for the country to start its journey towards success. Women hold up half of the sky above us, without them, the sky will fall. Even in patriarchal cultures, it needs to be understood that growth is intrinsically linked with the female workforce and participation. And not just participation and workforce, but also having women in positions of power and as decisionmakers.'

She negated the statement that we (Pakistani society) should have a local version of empowerment that is different from the one in the west. For her, the east and west divide becomes very dilute when it comes to women's rights. Women across the world suffer from almost the same problems. For example, gaslighting is something that was

${ }^{30}$ Dr Huma Baqai is an Associate Professor and Dean of Social Sciences and Liberal Arts, and Former Associate Dean, faculty of Business Administration, IBA Karachi. (https://humabaqai.com/) 
conceptualized in the west, but is faced by almost 80 percent of the women in Pakistan too. Women can be in positions of power outside their homes, but inside, they are constantly pushed down, looked down upon, and condescended. Inflicting low-esteem in women is a tool used by patriarchal societies all around the world, to hold women back. No matter how talented or skilled a woman is, she always second-guesses herself and doubts herself because this is internalized in them, they are conditioned to think this way since they are born. During the discussion, we felt that it is important to take affirmative action. Because vulnerable groups that have been left behind, including women, need affirmative action to come at par. And this does not just mean setting up quotas, it means that the recognition of the constraints with which women work, takes place. For example, there is always a bias against a young woman who isn't married. We never hold this up against a male, but a female will always be judged on her marital status as it is assumed that she won't be able to work properly after marriage or motherhood. Now, this is holding women back.

Homemaking and nurturing children is also an important job that is essentially done by women. This labor is not only unpaid, but also unrecognized, unappreciated, and overlooked. This is not seen as an important contribution to society and even women are completely fine with it. Most women look down upon the other women who decide to pursue their careers. We need to change this perception that it is not possible to pursue a career and be a homemaker at the same time because women can do this, and have been doing this if they are enabled by the state and society. And this is not the need of women themselves, but rather of the state and the society to progress.

Thus, we need to stop blaming women for what the state hasn't been able to do for them and society creates constraints for them. As far as the causes of low social mobility in Pakistan are concerned Dr. Huma Baqai pointed out that there are two powers at work, the power of status quo, and the power of change. The changing role of women directly threatens the status quo, and it is difficult to change an existing paradigm. The fact that women do so much unpaid labor is mainly responsible for the drastic changes that women empowerment and social mobility can bring about in society. It will create a need for old homes, day-care centers, take-outs, etc as the status quo will be challenged, and women will stop lifting the enormous load of the whole society they have been lifting silently without any payment or recognition. The constructs of the patriarchal society are such that even education is an extreme privilege for girls, hence, women are pulled out of the race even before it starts.

Moreover, when we talk about women who are earning money, the question to be asked is that do they have any control over their own money? Most of them don't. They are expected to contribute to the finance of their houses while also doing the housework without any help from their male family members. This puts a lot of strain on them and further prevents them from climbing the social ladder. For Dr. Huma Baqai, another important concept to be looked into is reflective glory. A woman is completely fine with applauding and glorifying the success of her husband, brother, or father. But she does receive the same applause from any of them except her father. The success of a woman is always seen as a threat to the dignity of her husband. He cannot even imagine being known by his wife's name, while his wife could spend her whole life known by his name. This 
fragile male ego is one of the biggest obstacles standing between a woman and her success.

We also discussed the same topics and enquired the same questions with Ms. Ameena Saiyid. ${ }^{31}$ (a renowned publisher and an entrepreneur) She shared her journey to answer the question that whether it is possible to empower Pakistani women and whether it is easy to achieve higher social mobility. Her journey was very similar to any common Pakistani woman's journey of establishing her career within a traditional society mainly dominated by men. The expectations from working women are always high, as they have to work on both fronts. It was not easy for her to establish her repute as a successful professional, but also had to maintain a balance in her work and family life. She raised her children along with her career development. To manage her work life, she had to set rules for herself. She preferred not to work on weekends, but in case of meeting crucial deadlines, she used to attend her office on off days.

Similarly, when there was something important in the family, Ms. Amena confined the working hours to the working days only. Without managing work and family life, and settling things back at home, a Pakistani woman would face more difficulties in reaching the higher position of her career. Ms. Ameena Saiyid was optimistic as far as the pace of human development and women empowerment is concerned. She recognized that even though at a slow pace, but Pakistani society is, nevertheless, changing. Due to the constant economic instability, women have been granted a low level of liberty for earning and money-making.

Men in our society have now been convinced to give their women freedom to step out from their homes or to work from home to share the financial burden. Though the upper hold of men as the major bread earner of the family has not altered and the decisionmaking power is mostly in the hand of male family members, but the finances and decision-making powers of the families are being shared by both men and women. This change in managing and sharing household expenditures is empowering the women from their previous subservient position to equal stakeholders.

Amena Saiyid explained that the problem of social mobility in our society lies in the traditional mindset. The majority of the population is illiterate and entrapped with feudal customs and traditions where women are considered inferior and incapable of taking charge of their life. The role of government is important in educating the people about gender equality, human dignity, and providing equal access to opportunities. The policies regarding human development and social mobility are inadequate to meet the social challenges. The trends in the labor market show negative for the women laborers. The problem is multifaceted and a more sound policy with a tangible action plan is required to socially mobilize not only the women but to all citizens.

As far as the western model of women empowerment is concerned she explained that our society and social order are based on a very different set of social norms and values. We do not need to employ a Western version of empowerment which is constructed on their

${ }^{31}$ (News 2020) Ameena Saiyid is the Managing Director, Lightstone Publishers Pvt Ltd, Founder and Director, Adab Festival 
own set of social norms. Instead, we must empower both our men and women while ensuring the importance of the continuation of social norms and values progressively and subtly. Our society has more space and width in adjusting and nurturing the working woman. The respect and privilege given to the woman are still considered as a high value in our society. We must not let it fade away by adopting a hardcore Western-made model of women empowerment. Women, in this struggling phase of empowerment and development, need more support and encouragement not only from their families but also from the legal, social and political system of Pakistan. As far as Pakistani women are concerned she is quite optimistic that our women are brave, strong, and equally competent. The women from lower-income classes living in the small cities and towns have a strong urge of improving their living standards. Their decision to become economically independent is stirred because of the tough circumstances and poor financial status, unemployment, and insufficient income/wage packages of their male counterparts. Things have been changed because of the changing realities.

Though men still have a decisive voice in the families, women do have an increasing influence gradually. Men in Pakistan have now understood the importance of women's participation and cooperation in economic wellbeing. They are supporting and facilitating women in managing their work and households. Though this is just a beginning but seems promising when we look towards the women running small business setups, getting out of their homes for education, and taking control of their life. The work efficiency level and commitment are higher among women workforce which is a bit uncomfortable for men, but with increasing social mobility within our society and progress in the human development sector, the situation will become better.

Another promising entrepreneur Mrs. Riffat Sabzwari ${ }^{32}$ (an entrepreneur) explained that many of the issues are self or socially constructed. A woman is always raised with a fear of being exposed to undesirable and uncertain situations. We do not give much confidence and trust to our girls while raising them and especially when sending them out for work or education. They are not trained and guided properly on how to face the real challenges of practical life, similarly, we do not have acceptability for working women battling on both fronts. She has witnessed highly competent and ambitious female resources who had to quit their careers at their prime time because they were not facilitated and supported by their husbands and in-laws. Social mobility in Pakistan doesn't confine to a women's access to external opportunities, it starts first with accessing the freedom to get outside opportunities while inside their homes.

Ms. Riffat thinks that limited freedom and scope to flourish a woman, hurdles in the way of their progress due to their marital life commitments, lack of social acceptability for the women who go out from homes to build their career. Many employers intentionally avoid hiring married females as they do not want to disrupt the workflow in case of pregnancy and other domestic matters. These are the real issues a large number of the female workforce have to deal with during hiring time. As a founder of Four Corners Group, she thinks that female leaders are often more empathetic towards their workers but this must not be generalized to all individual leaders. People cooperate with the working system if

${ }^{32}$ (group n.d.)https://www.fourcg.com/about-us/ 
their self-respect remains intact and respected by the leader. But being women we have an edge of understanding both sides of your workers' life. For her, empowerment is the solution. It unlocks all the 'ifs and buts', and leads you to the path which holds a bulk of unexplored opportunities. An empowered woman shares her light with all the people related to her. The power she gained by freeing herself from fear of being labeled negatively, will give her more strength to bring prosperity to the home.

Empowered women work hard, they have the qualities of tolerance, positivity, and persistence. It is important not to count the problems and difficulties, as women we should count on our strengths. Optimism will enable us to face challenges and limitations without compromising our dream. It is important to hammer our minds daily to see the opportunities, focus on our goals, and always find the solutions and alternates. Each time we will learn a new way to come out of a challenge so that we will become more empowered. As women's empowerment in our society all depends upon the cooperation of men. Not only men the role of the women of their families is equally important. It is inevitable to invest in the human development of men and women both if you want to have independent and strong women and an empowered society at large.

As far as the western model is concerned Riffat explained that it demands a 360-degree change in mindset, social values, and norms which would not be suitable for our existing social order. Adopting an alien model of empowerment may cause an unnecessary clash within the social system. Pakistan has a strong family system where each gender has space and opportunity to flourish. Overlapping the roles and overthrowing the social order may be chaotic and undesirable, not even recommended by me.

A large number of women in Pakistan are attached to the beauty business. The pioneer of the beauty business in Pakistan Mrs. Ruhana Iqbal (a renowned beauty expert). ${ }^{33}$ As per Mrs.Iqbal, it is inevitable to empower women by providing them different opportunities. As it is important in today's world to increase the size of the labor market. Now it is difficult for a man to feed the entire family. Hence, it is important to educate the women so that they can become progressive citizens, it is important to empower them so that they would be able to become efficient decision-makers and groom confident generation and to polish their skills so that they can take part in economic activities efficiently.

As far as low-income groups are considered they are treating women as their slaves. Women are working for long hours and are not only raising their kids but they are contributing a lot to raise their family income but as far as their role in decision making is concerned it is minor. Women are not even allowed to draw their salaries themselves as their spouses usually take their salaries and spend with their own will.

But the scenario is not the same in middle and upper-class families as Mrs. Iqbal has experienced the educated families usually allow their women to upgrade their skills, they seek their advice in the decision-making process. Therefore it is important to educate men and women. For Mrs. Iqbal, it is important not only to groom the skills of the men and women but also to develop them so that they can become productive and sensible citizens. But when we talk about women empowerment it is important to talk about human

${ }^{33}$ (VYMaps.com n.d.) https://vymaps.com/PK/Bhabi-s-Health-Beauty-Clinic-445990198821513/ 
development. Because responsibility increases with the increasing roles. The broadminded and educated individuals understand the importance of women's involvement in economic activities. Therefore educated women will be able to handle the power with courage and in a dignified manner. While women are going out to perform their social and professional duties she is not only representing her own family but is representing the whole gender. Her wrong moves and irresponsible behavior can affect the career of thousands of other girls. Mrs.Iqbal has personally groomed thousands of girls and they have changed the structure of their families. It is important to provide and produce our version of women empowerment as our socio-cultural, religious, and historical factors influence our behavioral patterns and expectations. The concept of absolute independence is unacceptable and cannot be tolerable in our socio-cultural fabric. Hence our expectations concerning power and mobility increase. Absolute freedom is a concept that exists in the west but it is not acceptable in our environment as ours is a collective society, the actions and decisions of one individual make a great impact on other individuals.

\section{Conclusion}

It is now a worldwide consensus that no country can prosper without the participation of women in its economy and leadership. As of now, Pakistan lags extremely behind in using the potential of its female population and providing it with equal opportunities careerwise. These issues can only be solved if the government takes an active interest in solving them. There are several measures the government can take to empower its female population. Only around $10 \%$ of Pakistani women receive post-secondary education which is a very alarming statistic. It is integral that the government provides easy access to education but at the same time puts extra attention to overall human development. Women are the poorest of the poor in our economy, enabling them to uplift their economic and financial standards will ensure a more progressive and meaningful contribution from their side which makes half of the total population. Besides working on women empowerment there is a need to educate and train Pakistan men because in a patriarchal society like ours the role of men in nurturing and enhancing women development plans is essential. Pakistani women to consider this need for men's equal participation in empowering themselves. The dynamics of home economics, joint family and domestic values, and socio-religious setup doesn't give space to a western-made empowerment model. Pakistani women need a cohesive and inclusive society that includes the support of all socio-economic stakeholders so that the benefits of empowerment may reach from individuals to the families and the larger groups.

Summing up the in-depth interviews, this article presents few suggestions

1. A rigorous Women Empowerment Policy by the government is equipped with a powerful monitoring and implementation mechanism.

2. Legal protection to women with easy access in immediate action.

3. Lodging a nationwide, state-sponsored media campaign. A positive and strong national narrative is indispensable to empower the minds and the souls first. 
4. Induction of a drastic and coherent and undisputed policy to meet the challenges of human development and women empowerment in Pakistan. Considering women's participation, development, and empowerment as the focal target may serve both purposes.

5. Inclusion of all sectors of society and especially the cooperation of male members of the society will be required to see analogous benefits.

6. Adequate fund supplies and allocation, better infrastructure, and a pragmatic approach will be needed to make the severity turn into an opportunity for change.

The challenge of human development and women empowerment with special reference to social mobility requires further inquiries. The length and breadth of this topic makes it difficult to explain all the necessary aspects, but through this article, an attempt has been made to share the theoretical and practical application of the said concepts.

\section{Bibliography}

(News 2020) Ameena Saiyid is the Managing Director, Lightstone Publishers Pvt Ltd, Founder and Director, Adab Festival (group n.d.)https://www.fourcg.com/about-us/

(VYMaps.com n.d.) https://vymaps.com/PK/Bhabi-s-Health-Beauty-Clinic-445990198821513/

Ahmed, Syed Shujaat. "Human development in Pakistan: challenges and way forward." Daily Times, 12 27, 2019.

America, Measure of. About Human Development. n.d.

https://measureofamerica.org/humandevelopment/\#: :text=Human\%20development\%20is\%20defined\%20as,a nd $\% 20$ improving $\% 20$ their $\% 20$ well $\% 2$ Dbeing.\&text=The $\% 20$ human $\% 20$ development $\% 20$ concept $\% 20$ was $\% 2$ Odeveloped\%20by\%20economist\%20Mahbub\%20ul\%20Haq. (accessed 0311,2021 ).

Bank, Asian Development. Women in Pakistan. Islamabad: Programs Department (West) and Programs Department (West), ADB, 2000.

beecher-stowe-quotes-3530095 (accessed 11 05, 2020).

Deneulin, Sabina Alkire and Séverine. " Introducing the Human Development and Capability Approach (Chapter 2)." In An Introduction to the Human Development and Capability Approach: Freedom and Agency, by Lila Shahani Severine Deneulin, 1-22. Routledge, 2009.

Deneulin, Sabina Alkire and Séverine. " Introducing the Human Development and Capability Approach (Chapter 2)." In An Introduction to the Human Development and Capability Approach: Freedom and Agency, by Lila Shahani Severine Deneulin, 1-22. Routledge, 2009.

Department (West), ADB, 2000.

Dr Huma Baqai is an Associate Professor and Dean of Social Sciences and Liberal Arts, and former Associate Dean, faculty of Business Administration, IBA Karachi. (https://humabaqai.com/)

Fabricio E. Balcazar, Christopher B. Keys, and Julie A. Vryhof. "Empowerment." In Introduction to Community Psychology, by Olya Glantsman, Jack F. O'Brien, and Kaitlyn N. Ramian Leonard A. Jason. Montreal, Canada: Pressbooks, 2019. 
Forum, World Economic. Social mobility. World Economic forum, 2020.

Forum, World Economic. Social mobility. World Economic forum, 2020.

Fund, United Nations Population. Women Empowerment. Issue 7, Cairo: UNFPA, 1994.

https://www.goodreads.com/quotes/37892-you-educate-a-man-you-educate-a-man-you-educate

https://www.reference.com/world-view/many-women-world-a8e6facca00d95b6

Jain, S. (2020). Human Development, Gender and Capability Approach. Indian Journal of Human Development. 14(2), 320 -322.

Kabeer, Naila. "Resources, Agency, Achievements:Reflections on the Measurement of Women's Empowerment." In Discussing Women's Empowerment, by Anne Sisask, 17-57. Stockholm: Sida studies, 2001.

Lewis, Jone Johnson. harriet-beecher-stowe-quotes. 07 03, 2019. https://www.thoughtco.com/harriet-beecherstowe-quotes-3530095 (accessed 11 05, 2020).

LUMS. Mahbubulhaq research centre. n.d. https://mhrc.lums.edu.pk/history-3 (accessed 10 31, 2020).

Mahbubulhaq. Reflections on Human development. Berlin: Oxford University Press, 1995

Nussabaum, M. Women and Human Development:A Study in Human Capabilities. . Cambridge: Cambridge University Press, 2000.

Pitirim Alexandrovich Sorokin was a Russian born, American, sociologist and political activist, he introduced the social cycle theory

Sen, Amartya. Development as freedom. New York: First Anchor Books, 2000.

Sen, Amrtya. Development as Freedom. Oxford: Oxford University Press, 1999

Stewart, Frances. Capabilities and Human development. New York: UNDP, 2013.

Tandon, Dr Tanu. "Women Empowerment: Perspectives and Views ." The International Journal of Indian Psychology, 2016: 6-16.

Tribune, Express. "Pakistan ranks 154th on UN's Human Development Index." The Express Tribune, 03 09, 2021.

UMS. Mahbubulhaq research centre. n.d. https://mhrc.lums.edu.pk/history-3 (accessed 10 31, 2020).

UNDP. Human Development Report. New York: Palgrave Macmillan, 2009.

UNDP. United Nations Development Programme. Oxford: Oxford University Press, 1990. (the new concept of Human development was introduced in 1990 for promoting human wellbeing)

UNDP. United Nations Development Programme. Oxford: Oxford University Press, 1990.

Venator, Richard V. Reeves and Joanna. Women and Social Mobility: Six Key Facts. April 03, 2014. https://www.brookings.edu/blog/social-mobility-memos/2014/04/03/women-and-social-mobility-six-keyfacts/ (accessed 11 20, 2020). 